\title{
An Analysis on Regulation on Optimizing the Business Environment: From the Perspective of Law
}

\section{Sisi Li*}

School of Public Administration, Sichuan University, No.24 South Section 1, Yihuan Road, Chengdu 610065, Sichuan, China. E-mail: cissy19@163.com

Abstract: Chinese State Council officially promulgated Regulation on Optimizing the Business Environment on October 23, 2019, which was formally implemented on since 2020, laying a solid foundation for the optimization of business environment in the direction of legalization. From the perspective of law, business environment ruled by law involves scientific legislation, standardized law enforcement, diversified legal remedy and judicial justice. Generally, business environment includes marketization, internationalization and legalization. And business environment ruled by will further promote its marketization and internationalization as a powerful guarantee.

Keywords: Regulation on Optimizing the Business Environment; Business Environment Ruled by Law; The Perspective of Law

\section{Introduction}

The most direct purpose of optimizing business environment is to stimulate the creativity and vitality of market players to a greater extent, so as to promote the sustained and healthy development of economy and create good material conditions for people's life. Therefore, fundamentally speaking, it is to liberate and develop productive forces, which is also the fundamental purpose of China's reform and opening-up. Looking at the reform process of more than 40 years, one of its experiences is to always adhere to the rule of law which means to promote the reform process with the law and to consolidate the reform achievements with the law. The optimization and improvement of business environment depends on the deepening development of reforms to streamline administration, delegate Powers, and improve regulation and services.

The promulgation of Regulation on Optimizing the Business Environment (hereinafter referred to as the Regulation) is one of the phased achievements made in current reforms. It not only raises the excellent experience accumulated in the deepening reform of "release, management and service" to the height of law, but also promotes the reform of our country to continue to move forward in the direction of having laws to abide by and laws to abide by. Business environment and the legalization of business environment, as one of the terms rising in the field of public management and law in China in recent years, has aroused great academic interest in the academic community, and has carried out a lot of in-depth and detailed research, and continued to provide China's program in global governance, which has played a promoting role in enhancing China's voice in the international community.

\section{Understandings of business environment}

Copyright (C) 2020 Sisi Li

doi: 10.18282/bam.v2i1.1095

This is an open-access article distributed under the terms of the Creative Commons Attribution Non-Commercial License

(http://creativecommons.org/licenses/by-nc/4.0/), which permits unrestricted non-commercial use, distribution, and reproduction in any medium,

provided the original work is properly cited. 


\subsection{Cognization in the official statements}

The name of business environment is not local and it originated from Doing Business which was published by World Bank since 2003. According to official documents and speeches, it mainly experienced the following development and changes in China. As one of the earliest areas of reform and opening-up pilot zone, Guangdong province carried out researches on optimizing business environment in 2012, which was the first time that business environment was mentioned. Since 2015, Premier Li Keqiang mentioned ranking of China's business environment worldwide in the speech at the teleconference on reforms to streamline administration, delegate powers, and improve regulation and services for five consecutive years, so as to provide international impetus for deepening domestic reform by benchmarking the international advanced level. In 2019, one of the themes of teleconference is to optimize business environment, it is pointed out that to optimize business environment through deepening current reforms, fundamentally speaking, is to liberate and develop the productive forces ${ }^{[1]}$. Xi Jinping stressed at the sixteenth meeting of the central financial and economic leadership group that a stable, fair and transparent business environment should be created ${ }^{[2]}$. The Fourth Plenary Session of the 19th Central Committee of the Communist Party of China also put the reform of business environment as one of the main tasks of optimizing the government responsibility system. It can be seen that in recent years, our country increasingly attaches great importance to the optimization and improvement of business environment. Nonetheless, a clear definition of business environment is not given from the official documents and speeches, which promotes the academic community to carry out relevant research to a certain extent.

\subsection{Cognization in the academic field}

The consensus on the business environment is still not reached in the academic community because this exotic concept covers a wide range. From the perspective of the relationship between government and market, it mainly involves two different inclination. One is to emphasize the government's responsibilities and roles in the shape and construction of business environment. For example, Hou Xiangdong (2019) defines the business environment by dichotomy of government environment and external environment, but emphasizes the role of government more ${ }^{[3]}$. Lou Chengwu and Zhang Guoyong (2018) propose that business environment reflects the level of government governance capacity to a certain extent, and it has increasingly become a new arena of governance innovation in China ${ }^{[4]}$. The other one is that some scholars who are mostly influenced by Doing Business elaborate it from the perspective of facilitating market participants. For instance, Song Linlin and He Chengxiang (2018), Yang Lihua and Dong Zhiyong (2019) summarized the definition of business environment in Doing Business according to the indicators adopted by World Bank for business environment assessment of various countries ${ }^{[5,6]}$. From the perspective of externality, some scholars Liu Gang and Liang Han put forward that the essence of optimizing business environment is to create a good external economic environment for enterprises and reduce institutional transaction costs ${ }^{[7]}$. By comparing these two inclinations, neither directly emphasizing the role of the government or attaching importance to the legitimate interests of the market participants, it is found that they both support the indispensable position of the government in the optimization of business environment.

\subsection{Definition by the Regulation}

Article 2 of the Regulation clearly states that "the business environment referred to in the Regulation refers to the institutional factors and conditions involved in market economic activities of enterprises and other market entities". From the legal level, the definition of the concept must grasp the principle of relaxation and degree. There should be a certain degree of discretion, but it must also be limited within the legal scope. The Regulation takes the market participants as the object and put them in the specific scope of market economic activity field so as to define the business environment, which is related to the "institutional factors and conditions", leaving a large room for discretion. Based on the above analysis, and in order to understand it as comprehensively as possible, this paper reckons that business environment is related to politics, economy, culture, diplomacy, law and other related factors, which can cause market participant to obtain and maintain their legitimate interests in the market environment. It directly reflects the sustainable 
strength of economic development in a certain region, which is related to the governance ability of local government, so it reflects the level of government governance ability and the improvement of governance system in a deeper level, and it has also increasingly become one of the important influencing factors in the current international competition.

\section{Analysis on the Regulation from the perspective of law}

Since the 18th National Congress of the Communist Party of China, our party and the state increasingly paid more attention to the important role of law in governing the country. The decision adopted at the Third Plenary Session of the 18th Central Committee of CPC proposed to build "a legal business environment". Premier Li Keqiang pointed in the teleconference on deepening reforms streamline administration, delegate powers, and improve regulation and services, that the direction of optimizing the business environment in the future is to adhere to the "three principles", and clearly put forward that "business environment ruled by law should create an open, transparent, fair and legal environment, to give stable expectations for market players"[1]. Although business environment has different dimensions, such as market environment and international environment, it is undeniable that the rule of law is the best business environment as marketization and internationalization can be realized steadily with legal guarantee. To some extent, optimizing business environment is to promote the legalization of business environment. Dong Biao and Li Renyu take the initial formation of the legal system, legal remedy paths and the transformation of government functions as the crucial aspects to measure the legalized business environment ${ }^{[8]}$. Sui Hongming believes that business environment ruled by law is related to national political stability and people's security, and is conducive to promoting the comprehensive rule of law and modernization of national governance ${ }^{[9]}$. Although the legalization of business environment and business environment ruled by law are only the differences in word order, they have different connotations: the former describes the ideal blueprint for the legalization of business environment in theory, while the latter dynamically promotes the ideal construction from the practical level. It is believed that with the promulgation and implementation of the Regulation, the goal of legalizing the business environment to the actual construction of business environment ruled by law will be gradually achieved.

Obviously, business environment ruled by law is an effective limitation of business environment in the legal field, not just a simple superposition of business environment and the rule of law. From the perspective of law formulation and implementation, the legalization of business environment includes scientific legislation, standardized law enforcement, diversified legal remedy and judicial justice.

\subsection{Scientific legislation}

In terms of passing a law, the scientific legislation is firstly manifested in the legislative procedures. The Regulation strictly abides by the provisions of articles 65 to 71 of the Legislative Law from the drafting to the formulation and then to the promulgation. In May 2019, which was the initial stage of the formulation of the Regulation, it would be incorporated into the 2019 legislative work plan of the State Council and approved by the CPC Central Committee and the State Council. In the mid-term, it mainly solicits opinions and conducts field research on the Regulation. On July 14, the National Development and Reform Commission (NDRC) took the lead and drafted the Regulation (Draft) to solicit opinions from the public. From July 15 to the end of August, the general director of NDRC led a team to Shenzhen, Shanghai, Quzhou, etc., and held 15 special meetings to extensively listen to opinions from deputies to the National People's Congress, committees of the Chinese People's Political Consultative Conference, the municipal Party committees, industry associations and enterprises. On October 8, the executive meeting of the State Council was held to examine and approve the Regulation (Draft) and made relevant amendments. On October 22, the premier signed the State Council order and passed it on the 23rd through official media. So far, the Regulation, which lasted nearly half a year, was successfully promulgated. Secondly, in the process of formulating the Regulation, the relevant departments actively listen to and adopt the opinions of all sectors of the society and respect the authoritative opinions of experts, so as to ensure that the contents of the Regulation conform to and reflect the needs of the people, especially the market entities. Finally, the contents of the Regulation also reflect the scientificity of legislation. For example, Article 61 stipulates that 
the relevant legal provisions should be amended and repealed in a timely manner, and authorized legislation pilot projects should be allowed. Article 62 stipulates that the formulation of relevant laws must listen to the opinions of all parties in the market. Generally speaking, the Regulation is composed of 72 articles in seven chapters. Apart from the first chapter of general provisions and the seventh chapter of supplementary provisions, the second chapter to the sixth chapter is market subject protection, market environment, government services, supervision and law enforcement, and legal protection, which embody the concept of people-oriented and legislation for business.

With the formulation and promulgation of the Regulation, local governments have followed the pace, even in front of the country, and introduced their own regulations in combination with local reality, such as Liaoning, Guangxi, Anhui, Shandong and other places. To a certain extent, it is conducive to improving the relevant legal system.

\subsection{Standardized law enforcement}

In terms of law enforcement, it is the key to realize the transformation from the state of ought to be to the state of reality. As the executor of public power, law enforcers must protect public interests when exercising their power. The premise of the standardization of law enforcement is the legal acquisition of administrative law enforcement power, including the legal subject and the legal source, that is, the authority is legal. In the legalization of business environment, administrative law enforcement is mainly manifested in the supervision and service of market economic activities. Chapter 4 and Chapter 5 of the Regulation have a total of 27 articles with clear provisions on administrative services and supervision and law enforcement, so as to promote the strict regulation of administrative law enforcement. For example, Article 35 clearly stipulates that the examination and demonstration of the newly established administrative license must be legal and reasonable, and strictly abide by the provisions of the "administrative license law" and relevant laws and regulations. Article 58 clearly stipulates that law enforcement organs shall abide by three administrative law enforcement systems. In a broad sense, the Regulation formulated by the departments of the State Council is also law. Taking Article 52 "the relevant departments of the State Council shall formulate unified, concise and easy-to-use regulatory rules and standards in different fields and make them public to the public” for instance, it puts forward three requirements for "regulatory rules and standards": national unity, simplicity and openness. It is required that the regulatory measures of government departments should be institutionalized, that is, stable, clear and transparent. The government should inform the market entities in advance of their reaction to their actions, give them stable behavior expectations, and increase the market participants' confidence in business environment, so as to promote the construction of business environment ruled by law. On the other hand, non-public, opaque or unclear regulatory information will make it challenging for market participants to predict the consequences of their actions and even make some wrong decisions, which will damage their own interests. On the other hand, it will increase the cost of law enforcement, and even lead to the lack of information of the public, resulting in difficulties in supervision and questioning the governance ability of the government ${ }^{[10]}$.

\subsection{Diversified legal remedy}

If disputes among market participants cannot be solved in time, not only the parties involved in the market, but also the public may be harmed, which will affect the public interest. When citizens' legal rights are infringed illegally, they should seek corresponding legal remedy to safeguard their own legal rights, which has become the social psychology recognized by modern society. According to the standard of whether it is directly involved by law, the remedy methods can be divided into legal relief and non-legal relief. The former includes administrative remedies such as seeking judicial relief from the court, administrative reconsideration, administrative litigation, etc., which has high authority and compulsion, but the cost of remedy is relatively high. The latter is mostly resolved and adjusted by social organizations such as arbitration institutions and legal associations to solve the contradictions and disputes between commercial entities, and the cost of this remedy is low and efficient but the authority is relatively weak. In the face of a large number of disputes related to enterprises, we should not only improve the efficiency of dispute resolution, but also ensure its fairness and authority, and the diversified dispute resolution mechanism is the realistic path to achieve this goal. Article 
66 stipulates that "the State shall improve the diversified dispute settlement mechanism with organic connection and mutual coordination such as mediation, arbitration, administrative adjudication, administrative reconsideration and litigation, so as to provide efficient and convenient dispute resolution channels for market participants”, which provides guidance for safeguarding the legal interests of market participants. The development of arbitration institutions in some pilot free trade zones in China provides good experience for other places, such as Guangzhou and Shanghai.

\subsection{Judicial justice}

Judicial justice is a fundamental step in promoting the construction of a country ruled by law. It also plays an indispensable role in the process of legalization of business environment, which runs through the whole process of judicial trial, judicial supervision and judicial service. In August 2017, Several Opinions of the Supreme People's Court on Providing Judicial Protection for Improving the Business Environment (hereinafter referred to as the Opinions) was issued, which was greatly conducive to providing more powerful judicial protection and services for market entities. Judicial justice is first reflected in the fair handling of enterprise related cases according to law, earnestly safeguarding the legitimate interests of commercial entities and making them feel fair. Articles 6, 7, 10, 11 and 12 of the Opinions respectively give detailed judicial interpretations on the handling of foreign-related commercial and maritime affairs, pilot free trade zones, various contracts, finance and intellectual property cases, providing legal guidance for the trial of relevant cases in practice. Secondly, the legitimate and fair exercise of judicial power depends on judicial supervision. Therefore, procuratorate in all classes must play their legal supervision duties and severely crack down on the use of criminal means to intervene in economic disputes, and actively act in protecting human rights, property rights and regulating the operation of public rights according to law ${ }^{[11]}$. Finally, the provision of judicial services is not only conducive to the promotion of judicial justice, but also makes market participants feel humanistic care ${ }^{[12]}$. Article 15 of the Opinions further explains the cases within the scope of rapid trial, which is conducive to the establishment of "rapid trial mechanism". Article 68 of the Regulation stipulates that the government and its relevant departments should provide public laws such as notarization and judicial expertise legal services to optimize business environment.

\section{Discussion and conclusion}

Starting from the legalization of business environment, this paper discusses the four dimensions of service-oriented government, that is, the rule of law government, the sunshine government, the responsible government and the honest government. It is believed that with the deepening of the reform of "regulation and service", with the promulgation of the "Regulations" and the implementation of the relevant departments of local governments, the state-owned business environment in our country will surely move towards. At the same time, a good legal business environment will provide a good guarantee for the market-oriented business environment, so as to enhance the international attractiveness of China's state-owned business environment. The government will play a key role in promoting the process of government's satisfaction and service-oriented governance.

However, due to the author's lack of relevant legal knowledge and academic ability, there are still many limitations in the analysis of the Regulation and the conclusion. The following are some reflections on this study, hoping to provide some reference for similar research in the future: first, from the perspective of rule of law, the author analyzes the legalization of business environment according to the legal system and implementation, respectively from the four aspects of legislation, law enforcement, relief and justice. In the analysis, only pay attention to the upper level. In addition to adhering to the rule of law, marketization and internationalization are also important principles in the optimization of business environment. In order to emphasize the importance of rule of law, the author has neglected to pay attention to the other two principles in order to emphasize the importance of the rule of law. Thirdly, this paper focuses on the business environment. The attention of the market subjects of the participants and builders is not enough, only stay in the text analysis, lack of corresponding data support. 


\section{References}

1. Li K. Speech at the teleconference on reforms to streamline administration, delegate powers, and improve regulation and services, and optimizing business environment (in Chinese). Chinese Public Administration 2019; (7): 610.

2. Xi J. Hosted the 16th meeting of the central financial and economic leading group, emphasizing the establishment of a stable, fair and transparent business environment (in Chinese). Reform \& Openning 2017; (15): 161.

3. Hou X. On the status and function of government publishing in the business climate (in Chinese). Chinese Public Administration 2019; (2): 17-22.

4. Lou C, Zhang G. Research on the business environment from the perspective of governance: Internal logic and construction ideas (in Chinese). Journal of Liaoning University (Philosophy and Social Sciences Edition) 2018; 46(2): 59-65+177.

5. Song L, He C. The logic and path of China's administrative reform from the perspective of optimizing business environment: Based on the analysis of the World Bank business environment indicator system (in Chinese). Chinese Public Administration 2018; (4): 67-72.

6. Yang L, Dong Z. Construction of business environment from the perspective of marketization, facilitation and in accordance with the law (in Chinese). Studies on Socialism with Chinese Characteristics 2019; (5): 18-24.

7. Liu G, Liang H. Optimization of business environment from perspective of externality-Thoughts based on enterprise demand orientation (in Chinese). Chinese Public Administration 2019; (11): 52-59.

8. Dong B, Li R. Research on the construction of legalized international business environment in China-Based on the analysis of business environment report (in Chinese). Journal of Commercial Economics 2016; (13): 141-143.

9. Sui H. The significance, core and path of constructing business environment ruled by law (in Chinese). Qunzhong 2019; (10): 17-19.

10. Zhao H. The optimizing goal and evaluating criteria of Chinese local institutional environment for business (in Chinese). Journal of Shandong University (Philosophy and Social Sciences) 2019; (3): 108-114.

11. Fu F. The rule of law path to optimize the business environment in northeast China-From the perspective of strengthening local procuratorial function (in Chinese). Administration and Law 2019; 247(3): 86-95.

12. Xie H. China's train of thought and system on the assessment of environment in the rule of law for doing business - Based on the perspective of the rule of Law (in Chinese). Hubei Social Sciences 2019; 387(3): 140-149. 